\title{
Comparison of Superoxide Dismutase, Glutathione Peroxidase and Adenosine Deaminase Activities between Respiratory and Nocturnal Subtypes of Patients with Panic Disorder
}

\author{
Osman Ozdemir ${ }^{a}$ Yavuz Selvi $^{\mathrm{b}}$ Halil Ozkol $^{\mathrm{c}}$ Yasin Tuluce $^{\mathrm{c}}$ Lutfullah Besiroglu $^{\mathrm{b}}$ \\ Adem Aydin ${ }^{b}$

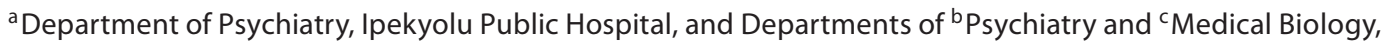 \\ Yuzuncu Yil University, Van, Turkey
}

\section{Key Words}

Adenosine deaminase $\cdot$ Glutathione peroxidase $\cdot$ Panic

disorder $\cdot$ Superoxide dismutase

\begin{abstract}
Objective: There is mounting evidence indicating that oxidative and inflammatory processes may have an important role in the pathogenesis of panic disorder (PD). PD is a heterogeneous disease, and panic attacks are divided according to the different symptom clusters as respiratory, nocturnal, non-fearful, cognitive, or vestibular subtypes. The aim of this study was to compare whole-blood and serum superoxide dismutase (SOD), glutathione peroxidase and adenosine deaminase activities in PD patients with/without nocturnal, respiratory subtypes and healthy subjects. Methods: The study was conducted including 60 patients with PD and 30 healthy control subjects. The Panic Attack Symptom Checklist, Panic and Agoraphobia Scale, Hamilton Depression Rating Scale and Hamilton Anxiety Rating Scale were administered to the patients. Biochemical analyses were performed after all the blood samples were collected. Results: We found that whole-blood SOD and glutathione peroxidase activities of patients were significantly lower and adenosine deaminase activities of patients were higher than those of
\end{abstract}

healthy controls. There were no statistically significant differences between respiratory and nocturnal subtypes. In addition, there were no marked relationships between the duration of illness and panic-agoraphobia scores of patients with nocturnal subtypes. Hamilton Depression Rating Scale and Hamilton Anxiety Rating Scale scores of patients with the nocturnal subtype were markedly higher than those of patients without the nocturnal subtype. Conclusion: The results suggest that oxidative and inflammatory processes may play a role in the pathophysiology of PD. These findings may support the idea that both nocturnal and respiratory subtypes of PD have different symptom clusters of the same disease.

Copyright $\odot 2012$ S. Karger AG, Basel

\section{Introduction}

Panic disorder (PD) is a relatively heterogeneous disorder that is characterized by the experience of recurrent unexpected panic attacks, encompassing a variety of somatic, physiological and cognitive symptoms, as defined in DSM-IV-TR [1]. In recent years, numerous researchers have investigated the symptom clusters, and a classification based on subtypes has been suggested. The literature

\section{KARGER}

Fax +4161306 1234

E-Mail karger@karger.ch

www.karger.com
(C) 2012 S. Karger AG, Basel

0302-282X/12/0664-0244\$38.00/0

Accessible online at:

www.karger.com/nps
Yavuz Selvi

Yuzuncu Yil University, Faculty of Medicine

Department of Psychiatry

TR-65200 Van (Turkey)

E-Mail dryavuzselvi@yahoo.com 
search revealed data pertaining to 5 potential symptom subtypes: respiratory, nocturnal, non-fearful, cognitive and vestibular $[2,3]$.

Nocturnal panic attacks (NPs) are characterized by abrupt arousal from sleep with a sense of impending doom, fear, palpitations, shortness of breath, chest discomfort, feelings of unreality, and hot or cold flashes. The symptom profile of NPs does not differ significantly from panic attacks that occur during wakefulness. Approximately $65-70 \%$ of PD patients report lifetime NPs, and $30-45 \%$ report recurrent NPs [4]. Patients with NPs reported higher rates of insomnia, especially non-restorative sleep and frequent awakenings $[4,5]$. Further studies with small samples have found higher comorbid depression in PD patients with NPs [6].

There is considerable evidence that the 'respiratory symptoms' group is a distinct PD subtype. Briggs et al. [7] studied 1,108 PD patients and found that those presenting with prominent respiratory symptoms showed significant clinical differences from those who did not. These symptoms were fear of dying, chest pain/discomfort, shortness of breath, paresthesia, and choking sensations. Patients were considered in the respiratory subtype group if they had 4 or 5 of these respiratory symptoms during the panic attack, whereas patients with $\leq 3$ of these symptoms were allocated in the non-respiratory subtype group $[7,8]$. Studies have demonstrated that the respiratory subtype patients feel a stronger sense of suffocation and have more panic attacks than the non-respiratory subtype patients during the carbon dioxide challenge test $[9,10]$. $\mathrm{Pa}$ tients with prominent respiratory symptoms suffered more spontaneous panic attacks and seemed to respond better to antidepressants, whereas patients with the nonrespiratory subtype had more situational panic attacks and seemed to respond better to benzodiazepines [8].

Oxidative stress (OS) is continuously produced by a free radical chain reaction in the cells. Free radicals (FRs) originated from molecular oxygen are generally known as reactive oxygen species (ROS) that are produced in many different ways, such as activation of phagocytes and the general immune system, lipid peroxidation, the electron transport system in mitochondria, ischemia and trauma [11]. OS occurs when there is an imbalance between generated ROS and clearance by the endogenous antioxidant defense system $[12,13]$. When FRs are produced in excessive amounts, or the enzymatic and nonenzymatic antioxidant defense systems are inefficient, some chain reactions causing cellular injury (or even death of cells) are activated $[14,15]$. There is mounting evidence indicating that ROS are involved in the develop- ment of neuropsychiatric disorders. FRs have been considered important in numerous psychiatric disorders including schizophrenia, bipolar disorder, depression, PD, and tardive dyskinesia [14, 16-19]. Since FRs have short half-lives, they can be evaluated indirectly by measurement of some antioxidant enzyme activities such as superoxide dismutase (SOD), catalase or glutathione peroxidase (GSH-Px).

$\mathrm{PD}$ is known to be associated with a high frequency of comorbid immunological diseases such as allergies and asthma [20]. Patients with PD have been shown to have enriched and increased expression of $\mathrm{T}$ lymphocytes compared to controls [21]. Adenosine deaminase (ADA) has been accepted as an important enzyme in the maturation and function of T lymphocytes. As an indicator of cellular immunity, plasma activity of this enzyme has been suggested to be increased in inflammatory diseases, which causes a cell-mediated immune response [22].

The etiology of PD is yet to be fully understood. It is suggested that ROS may have an important role in the pathogenesis of PD [14]. The present study aimed to compare SOD, GSH-Px and ADA activities in PD patients with/without nocturnal and respiratory subtypes and healthy subjects. The aim of this study was to evaluate the effects of OS and the inflammatory process on the pathogenesis of PD.

\section{Materials and Methods}

\section{Subjects}

The study included 60 patients ( 31 females, 29 males; age range 18-65 years) who had applied to the department of psychiatry and been diagnosed with PD according to the DSM-IV criteria [23]. Written consent to participate in the study was obtained from the patients after they were thoroughly informed about the research details. Approval of the study was given by the ethics committee of the Faculty of Medicine at Yuzuncu Yil University.

Exclusion criteria were alcohol and substance abuse or dependence, having psychotic and bipolar disorders, presence of severe organic disorders, presence of epilepsy or severe neurological disorder, presence of infectious and viral disease, or pregnancy.

Thirty controls were chosen from among healthy subjects who volunteered (14 females, 16 males; age range 18-54 years). Control subjects were free of any medication for at least 6 weeks prior to blood sampling. None of the control subjects were drinkers, heavy smokers or had ever taken psychotropic drugs. They had no history or family history of psychiatric disorder.

\section{Assessments}

Each patient underwent diagnostic evaluation by one psychiatrist on the basis of the Structured Clinical Interview for DSM-IV Axis-I Disorders; a sociodemographic form, the Panic Attack Symptom Checklist, Panic and Agoraphobia Scale (PAS), Hamil- 
ton Depression Rating Scale (HAM-D) and Hamilton Anxiety Rating Scale (HAM-A) were administered to the patients.

The sociodemographic form gathered such information as age, gender, marital status, educational condition, socioeconomic status, and duration of illness. The Structured Clinical Interview for DSM-IV Axis-I Disorders is used for diagnosing major DSMIV Axis-I disorders and is a structured clinical interview scale. This scale, developed by First et al. [24], was translated into Turkish by Corapcioglu et al. [25].

The Panic Attack Symptom Checklist was created by the 13 symptoms included in the DSM-IV-TR diagnostic criteria for PD. The symptoms on the list were chosen according to the last panic attack the patient has had. The severity of the panic attack was determined by the interviewer and scored as ' 0 ' (no occurrence), '1' (mild level), '2' (medium level), and ' 3 ' (severe).

PAS is a scale created by Bandelow [26] for assessing the severity of PD with or without agoraphobia. It takes into account the panic attacks, phobic avoidance, anticipatory anxiety, loss of ability, and preoccupations about health. There are separate forms for clinical observation and self-report. It has 5 subscales and each question is scored from 0 to 4 . Thirteen items of the total 14 items are scored.

HAM-D is a scale that measures the level and severity of depression. It contains 17 items, each of which is scored between 0 and 4 points. HAM-D was developed by Hamilton [27], and the validity and reliability of its Turkish form was confirmed by Akdemir et al. [28].

HAM-A measures the level of anxiety, symptom variation and changes in the severity of anxiety. HAM-A was developed by Hamilton [29], and the validity and reliability of its Turkish form was confirmed by Yazıc1 et al. [30]. The scale contains 14 items, each of which is scored between 0 and 4 points.

\section{Determination of Panic Attack Subtypes}

In the subtyping studies of PD, some accept DSM-IV-TR panic attack symptoms as sufficient criteria $[3,9]$, while others are evaluated within the context of other symptoms as well during the panic attack $[31,32]$. The current study accepted 13 symptoms in DSM-IV. An NP is defined as an abrupt waking from sleep in a state of panic involving subjective fear or discomfort along with cognitive and physiological symptomatology similar to that during a diurnal panic attack. The respiratory subtype requires 4 of the following 5 symptom criteria during an individual's most recent severe panic attack: choking or smothering sensations; shortness of breath; chest pain or discomfort; numbness or tingling sensations; and fear of dying [7]. The non-respiratory subtype is operationalized as that which does not meet these symptom criteria.

\section{Blood Sampling}

A 7-ml sample of venous blood was taken from each person included in the study. A 2-ml sample was taken in a tube with ethylenediaminetetraacetic acid for whole-blood analysis, and the rest was placed in ice-chilled siliconized glass tubes for serum analyses.

The samples were kept in a cool box at $+4^{\circ} \mathrm{C}$ until they were transferred immediately to the laboratory. The serum samples were obtained by centrifuging the blood samples at 3,000 rpm for $15 \mathrm{~min}$ at $4^{\circ} \mathrm{C}$. Whole blood samples were hemolyzed with deionized water. After centrifugation $\left(4,000 \mathrm{~g}\right.$ for $10 \mathrm{~min}$ at $\left.+4^{\circ} \mathrm{C}\right)$, up- per supernatant fluid was separated, and SOD, GSH-Px and ADA activities were measured at this stage, consistent with the method used by Selvi et al. [33]. The activities of these enzymes were also determined in serum. All samples were stored at $-40^{\circ} \mathrm{C}$ until analysis. The biochemical analyses were made after all the blood samples were collected. Laboratory analyses of investigation were conducted in the Department of Medical Biology, Faculty of Medicine, at the Yuzuncu Yil University.

Measurement of SOD Activity (EC 1.15.1.1)

SOD catalyzes the dismutation of two superoxide radicals $\left(\mathrm{O}_{\overline{2}}\right)$ into $\mathrm{O}_{2}$ and $\mathrm{H}_{2} \mathrm{O}_{2}$. SOD activity was assessed by determining inhibition percentage of formazan formation at $505 \mathrm{~nm}$ in whole blood and serum using commercially available kits (Ransod kit, Randox Laboratories Ltd., UK) on a spectrophotometer (Genesys 10 UV, Thermo Scientific). Activity was expressed as units per gram hemoglobin for whole blood and units per gram protein for serum.

\section{Measurement of GSH-Px Activity (EC 1.11.1.9)}

Whole-blood and serum GSH-Px activity was determined using the Glutathione Peroxidase Assay Kit (Ransel kit, Randox Laboratories Ltd., UK), which measures GSH-Px activity indirectly by a coupled reaction with glutathione reductase. The enzymatic reaction was initiated by adding $\mathrm{H}_{2} \mathrm{O}_{2}$ to the reaction mixture containing reduced glutathione (GSH), reduced nicotinamide adenine dinucleotide phosphate and glutathione reductase. The change in absorbance at $340 \mathrm{~nm}$ was monitored by a spectrophotometer (Genesys $10 \mathrm{UV}$, Thermo Scientific). Activity was given in units per gram hemoglobin for whole blood and units per gram protein for serum.

\section{Measurement of ADA Activity}

Whole-blood and serum ADA activities were determined spectrophotometrically by the method of Giusti [34], which is based on assessing the formation of ammonia $\left(\mathrm{NH}_{3}\right)$ produced while ADA acts in excess of adenosine. The release of $\mathrm{NH}_{3}$ was determined colorimetrically at $630 \mathrm{~nm}$ after the development of an intense blue color with hypochlorite and phenol in an alkaline solution. Results were expressed as units per gram hemoglobin for whole blood, units per gram protein for serum and were calculated as the mean and standard deviation.

\section{Measurement of Protein Content}

The protein content of serum was measured spectrophotometrically (Genesys 10 UV Scanning UV/VIS Spectrophotometer) by the method of Lowry et al. [35], with bovine serum albumin as the standard.

\section{Statistical Analysis}

Descriptive statistics were expressed as the mean and standard deviation for the continuous variables. Student's t test was used to compare the means of patient and control groups for these variables. In addition, Pearson's correlation analysis was carried out for determination of linear relationships among the variables. On the other hand, for the categorical variables, descriptive statistics were presented as count and percent, and the $\chi^{2}$ test was performed to detect relationships between these variables. Statistical significance levels were considered as $5 \%$, and SPSS (version 16) statistical program was used for all statistical computations. 


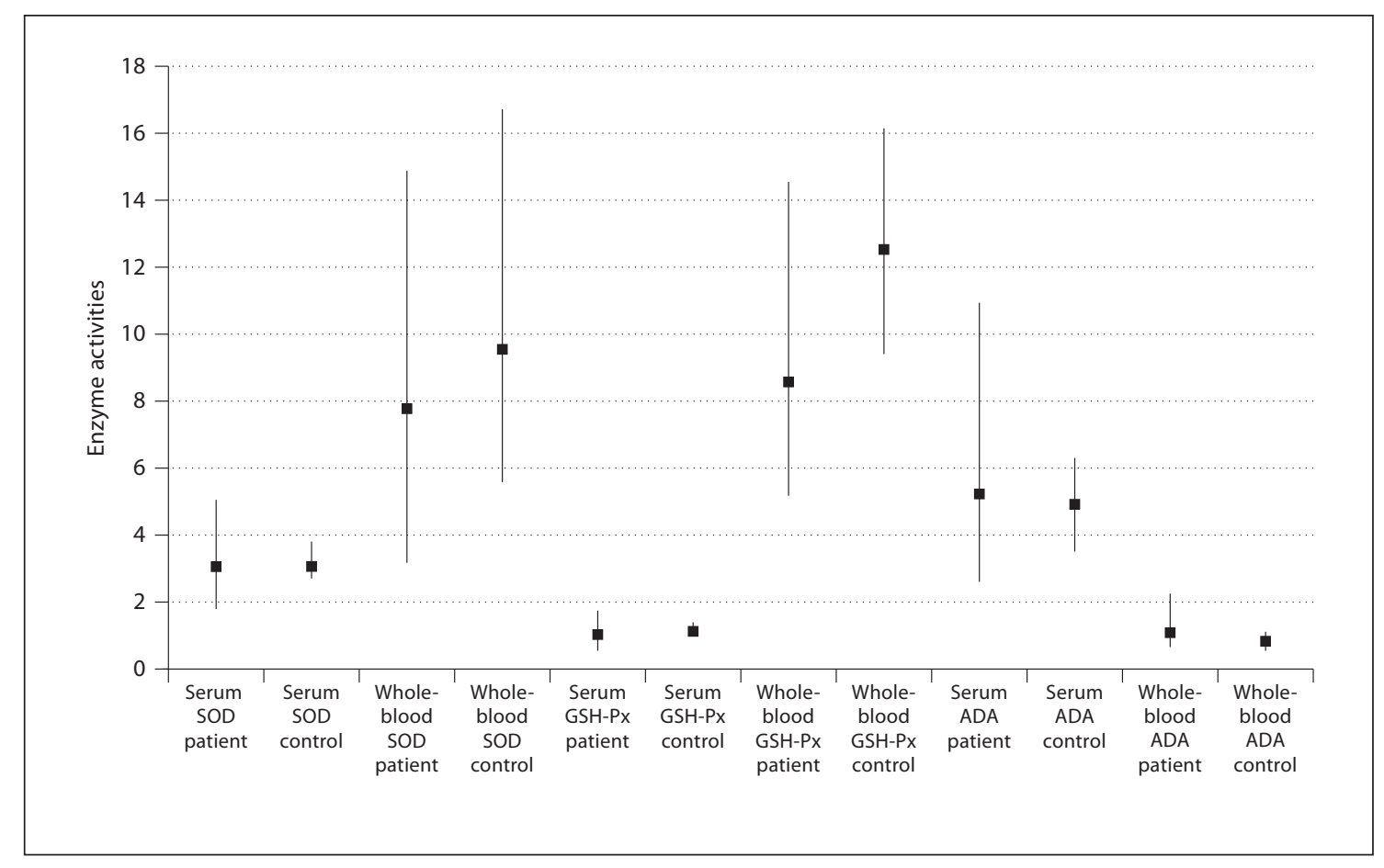

Fig. 1. Upper and lower values of enzymatic parameters in patients and control groups. Serum SOD is given in $\mathrm{U} / \mathrm{g}$ protein, whole-blood SOD in U/g $\mathrm{Hb} \times 10^{2}$, serum GSH-Px in U/g protein, whole-blood GSH-Px in U/g $\mathrm{Hb}$, serum $\mathrm{ADA}$ in $\mathrm{U} / \mathrm{g}$ protein $\times 10^{-2}$, and whole-blood $\mathrm{ADA}$ in $\mathrm{U} / \mathrm{g} \mathrm{Hb}$.

\section{Results}

Patients were divided into four groups according to their PD subtypes: nocturnal $(\mathrm{n}=31)$, non-nocturnal $(\mathrm{n}=29)$, respiratory $(\mathrm{n}=33)$ and non-respiratory $(\mathrm{n}=27)$. A total of 60 patients ( 31 females, $51.2 \%$; 29 males, $48.8 \%$ ), with a mean age of $34.1 \pm 10.8$ years were enrolled. Healthy controls $(n=30)$ consisted of 14 females $(46.7 \%)$ and 16 males (53.3\%), with a mean age of $32.4 \pm 7.9$ years. There were no significant differences in age or female/ male ratio between the patients/controls or nocturnal/ non-nocturnal PD subtypes ( $\mathrm{p}>0.05)$.

SOD and GSH-Px activities were significantly lower in the PD group compared to the control group. The mean ADA activity was higher in PD compared to controls (figure 1, table 1). There was no significant difference in terms of SOD, GSH-Px or ADA activities between both nocturnal/non-nocturnal and respiratory/non-respiratory subtypes ( $p>0.05$; tables 2,3$)$.

There was no correlation between the mean duration of illness and PAS in nocturnal and non-nocturnal subtypes; however, HAM-D and HAM-A scores of nocturnal subtype patients were higher than those of non-nocturnal subtype patients. There were no significant relationships between the duration of illness, PAS, HAM-D and HAM-A scores ( $p>0.05)$. In respiratory and non-respiratory groups when examining the correlations between these variables and enzyme activities, there was only a positive correlation between the duration of disease and serum activities of GSH-Px (table 4).

\section{Discussion}

In the present study, serum SOD and GSH-Px activities of patients with PD were found to be significantly lower than those of controls, and serum ADA activity was found to be higher. Lower activities of antioxidant enzymes (SOD and GSH-Px) in the PD group indicate the high level of OS in PD. Also, ADA activity, which is an indication of cellular immunity, indicates that inflammatory processes are involved and may also have an effect on the production of excessive amounts of FRs, the hampered antioxidative mechanisms or the pres- 
Table 1. Comparison of enzyme activities in patient and control groups

\begin{tabular}{lcccc}
\hline & Patient $(\mathrm{n}=60)$ & Control $(\mathrm{n}=30)$ & $\mathrm{t}$ & $\mathrm{p}$ \\
\hline Serum SOD, U/g protein & $3.09 \pm 0.60$ & $3.09 \pm 0.35$ & 0.291 & 0.77 \\
Whole-blood SOD, U/g Hb & $774.80 \pm 357.20$ & $955.11 \pm 317.68$ & 2.362 & 0.02 \\
Serum GSH-Px, U/g protein & $1.07 \pm 0.20$ & $1.13 \pm 0.14$ & 0.946 & 0.34 \\
Whole-blood GSH-Px, U/g Hb & $8.54 \pm 1.58$ & $12.52 \pm 1.71$ & 8.493 & 0.00 \\
Serum ADA, U/g protein $\times 10^{-2}$ & $5.23 \pm 1.78$ & $4.90 \pm 0.84$ & 1.028 & 0.30 \\
Whole-blood ADA, U/g Hb & $1.11 \pm 0.24$ & $0.86 \pm 0.14$ & 5.878 & 0.00 \\
\hline
\end{tabular}

Table 2. Comparison of enzyme activities in the nocturnal and non-nocturnal groups

\begin{tabular}{lcccc}
\hline & $\begin{array}{l}\text { Nocturnal subtype } \\
(\mathrm{n}=31)\end{array}$ & $\begin{array}{l}\text { Non-nocturnal subtype } \\
(\mathrm{n}=29)\end{array}$ & $\mathrm{t}$ & $\mathrm{p}$ \\
\hline Serum SOD, U/g protein & $3.02 \pm 0.51$ & $3.15 \pm 0.67$ & 0.819 & 0.41 \\
Whole-blood SOD, U/g Hb & $801.51 \pm 358.43$ & $740.77 \pm 359.92$ & 0.636 & 0.52 \\
Serum GSH-Px, U/g protein & $1.10 \pm 0.19$ & $1.04 \pm 0.21$ & 0.993 & 0.32 \\
Whole-blood GSH-Px, U/g Hb & $8.72 \pm 1.44$ & $8.33 \pm 2.01$ & 0.912 & 0.36 \\
Serum ADA, U/g protein $\times 10^{-2}$ & $5.11 \pm 1.68$ & $5.36 \pm 1.78$ & 0.517 & 0.60 \\
Whole-blood ADA, U/g Hb & $1.11 \pm 0.23$ & $1.11 \pm 0.26$ & 0.017 & 0.98 \\
\hline
\end{tabular}

Table 3. Comparison of enzyme activities in the respiratory and non-respiratory groups

\begin{tabular}{lccrc}
\hline & $\begin{array}{l}\text { Respiratory } \\
\text { subtype } \\
(\mathrm{n}=33)\end{array}$ & $\begin{array}{l}\text { Non-respiratory } \\
\text { subtype } \\
(\mathrm{n}=27)\end{array}$ & $\mathrm{t}$ & $\mathrm{p}$ \\
\hline Serum SOD, U/g protein & $3.01 \pm 0.53$ & $3.25 \pm 0.69$ & -1.442 & 0.15 \\
Whole-blood SOD, U/g Hb & $781.77 \pm 365.92$ & $757.51 \pm 358.43$ & 0.230 & 0.81 \\
Serum GSH-Px, U/g protein & $1.07 \pm 0.21$ & $1.10 \pm 0.19$ & 0.126 & 0.90 \\
Whole-blood GSH-Px, U/g Hb & $8.33 \pm 1.67$ & $8.72 \pm 1.44$ & -1.088 & 0.28 \\
Serum ADA, U/g protein $\times 10^{-2}$ & $5.12 \pm 1.69$ & $5.47 \pm 1.81$ & -0.680 & 0.50 \\
Whole-blood ADA, U/g Hb & $1.14 \pm 0.23$ & $1.06 \pm 0.26$ & 0.017 & 0.30 \\
\hline
\end{tabular}

Table 4. Correlations between enzyme activities and clinical variables

\begin{tabular}{lccrr}
\hline & PAS total & Duration of illness & HAM-A & HAM-D \\
\hline Serum SOD, U/g protein & -0.041 & 0.109 & -0.043 & -0.159 \\
Whole-blood SOD, U/g Hb & 0.104 & 0.166 & 0.128 & 0.152 \\
Serum GSH-Px, U/g protein & -0.220 & $0.338^{*}$ & -0.089 & 0.009 \\
Whole-blood GSH-Px, U/g Hb & -0.051 & -0.010 & 0.196 & -0.090 \\
Serum ADA, U/g protein $\times 10^{-2}$ & -0.093 & 0.131 & 0.160 & 0.146 \\
Whole-blood ADA, U/g Hb & -0.262 & -0.120 & 0.122 & 0.031 \\
\hline
\end{tabular}

$$
{ }^{*} \mathrm{p}<0.05 \text {. }
$$


ence of both resolution OS. The heavily proactive oxidative metabolism may be formed through physiological stress, pathogens or inflammatory responses. Genetic diversity and physiological factors affect the oxidative defense capacity of the individual. Such characteristics may bring about a predisposition in the pathogenesis of the disease in the persistence and the recurrence of symptoms [36].

Increased ADA activity suggests that inflammatory chemical mediators might be associated with symptoms of PD. There is already evidence for an interaction between PD and the immune system [37, 38]. PD patients often report stressors preceding the onset of panic attack $[39,40]$. The immune system is one of the most important stress pathways [41]. Stress can modulate immune response through nerve pathways connecting the autonomic nervous and immune systems by triggering the release of hormones and neuropeptides that interact with immune cells [42]. These effects may occur quite rapidly and have been shown to be associated with increased heart rate, blood pressure and circulating catecholamines which are symptoms of panic attacks $[42,43]$. Stress is not expected to have the same effects in all people [44]. Perhaps, individuals more prone to illness will experience panic attacks.

In previous studies, conflicting results were reported in patients with PD. Herken et al. [22] investigated the NO levels and activities of xanthine oxidase (XO), SOD and ADA in PD patients at baseline and after antidepressant treatment. They found that ADA and XO levels of the patients were significantly higher than in the healthy control group; and after 8 weeks of antidepressant treatment, ADA and SOD activities were increased whereas $\mathrm{NO}$ and XO levels were significantly decreased. In this study, SOD activity of the patients was lower than in the control group, but the difference was not significant. These findings suggest that ADA and XO activity may have a pathophysiological role in $\mathrm{PD}$, and that this could be used as a biological prognostic indicator of disease. In another study, we investigated ADA and dipeptidyl peptidase IV activities in patients with PD [41]. The ADA activity was observed to be increased in patients with $\mathrm{PD}$ and it was claimed that such an increase would also trigger an increase in cellular immunity. In contrast to our results, Kuloglu et al. [14] compared levels of some antioxidant enzymes in PD patients with a healthy control group and found that the mean GSH-Px, SOD and MDA levels of the patient group were significantly higher. On the other hand, Ersoy et al. [45] found that both the total antioxidant status and the total OS index were found to be significantly higher in PD patients compared with healthy controls. These findings showed that FRs might have a role in the etiopathogenesis of PD, but they need to be confirmed by further more comprehensive and detailed studies to decipher the exact roles of FRs in PD.

To our knowledge, this is the first study that has compared the activities of antioxidant enzymes and ADA between the nocturnal and respiratory subtypes of PD. The enzyme activities of nocturnal and non-nocturnal subtypes of PD are compared. Serum SOD and GSH-Px activities were found to be higher in the nocturnal subtype compared with non-nocturnal groups; however, this difference was not statistically significant. In the case of NPs, depression is more common [46], the clinical pattern is more severe, and more problems of insomnia are experienced [47]. Also, taking into consideration that insomnia increases OS, the higher activities of antioxidant enzymes, which are indirect indicators of OS in the nocturnal subtype, may be considered expected results. There were no statistically significant differences in terms of enzyme activities between respiratory and nonrespiratory subtypes.

In our study, we aimed to compare SOD, GSH-Px and ADA enzyme activities between PD nocturnal and nonnocturnal, respiratory and non-respiratory subtypes. There were no differences between groups. These findings indicate that these distinct symptom clusters are a variety of disease manifestation and not two different clinical entities.

The enzyme activities and the relationship between PAS total, duration of illness, HAM-D and HAM-A are analyzed. There was no correlation between total PAS, HAM-A and HAM-D scores, whereas there was a correlation between the duration of illness and GSH-Px activity. PD nocturnal and non-nocturnal, respiratory and non-respiratory subtypes were compared in terms of duration of illness, HAM-D, HAM-A and the scores of total PAS; the duration of illness in the nocturnal type was higher compared to the non-nocturnal subtype. However, this difference was not statistically significant. The HAM-D and HAM-A scores of the nocturnal subtype were found to be significantly higher compared with non-nocturnal subtypes. There are studies reporting more frequent major depression and agoraphobia comorbidity for NPs $[6,47]$. Therefore, the presence of NPs may be expected to lead to higher levels of anxiety and depression in patients. The total PAS, duration of illness, HAM$\mathrm{D}$ and HAM-A scores of the respiratory and non-respiratory subtypes were evaluated, and no statistically significant difference was found between them. 
Our study has one main limitation that should be mentioned. The findings are difficult to interpret because the patients were not on any medications, though the effects of drugs can have an impact on the results.
In conclusion, an adequate understanding of oxidative and inflammatory mechanisms in psychiatric disorders may be useful in the interpretation of etiology and treatment alternatives.

\section{References}

1 American Psychiatric Association (APA): Diagnostic and Statistical Manual of Mental Disorders. Washington, American Psychiatric Press, 2000.

-2 Kircanski K, Craske MG, Epstein AM, Wittchen H: Subtypes of panic attacks: a critical review of the empirical literature. Depress Anxiety 2009;26:878-887.

-3 Sarp A, Arik AC, Guz H, Sahin AR, Abanoz Z: Possible subtypes of panic disorder. Turk Psikiyatri Derg 2010;21:269-279.

4 Mellman TA, Uhde TW: Sleep panic attacks: new clinical findings and theoretical implications. Am J Psychiatry 1989;146:12041207.

5 Craske MG, Barlow DH. Nocturnal panic. J Nerv Ment Dis 1989;177:160-167.

-6 Agargun MY, Kara H: Recurrent nocturnal panic, insomnia, and suicidal behavior in patients with panic disorder. Compr Psychiatr 1998;39:149-151.

7 Briggs AC, Stretch DD, Brandon S: Subtyping of panic disorder by symptom profile. $\mathrm{Br}$ J Psychiatry 1993;163:201-209.

-8 Valence AM, Nardi AE, Nascimento I, Zin WA, Versiani M: Respiratory panic disorder subtype and sensitivity to the carbon dioxide challenge test. Braz J Med Biol Res 2002;35: 783-788.

9 Biber B, Alkın T: Panic disorder subtypes: differential responses to $\mathrm{CO}_{2}$ challenge. Am J Psychiatry 1999;156:739-744.

10 Abrams K, Rassovsky Y, Kushner MG: Evidence for respiratory and non-respiratory subtypes in panic disorder. Depress Anxiety 2006:23:474-481.

11 Gutteridge JMC: Lipid peroxidation and antioxidants as biomarkers of tissue damage. Clin Chem 1995;41:1819-1828.

12 Brown MK, Naidoo N: The UPR and the anti-oxidant response: relevance to sleep and sleep loss. Mol Neurobiol 2010;42:103-113.

13 Ozkol H, Koyuncu I, Tuluce Y: Some medicinal plants counteract alterations of neuroendocrine stress response system, oxidative and nitrosative stress caused by repeated restraint in rats. J Med Plants Res 2011;5:43604368 .

14 Kuloglu M, Atmaca M, Tezcan E, Ustundag B, Bulut S: Antioxidant enzyme and malondialdehyde levels in patients with panic disorder. Neuropsychobiology 2002;46:86-89.
5 Ozkol H, Tuluce Y, Koyuncu I: Subacute effect of cigarette smoke exposure in rats: protection by pot marigold (Calendula officinalis L.) extract. Toxicol Ind Health 2012;28: 3-9.

16 Atmaca M, Tezcan E, Kuloglu M, Ustundag B, Tunckol H: Antioxidant enzyme and malondialdehyde values in social phobia before and after citalopram treatment. Eur Arch Psychiatry Clin Neurosci 2004;254: 231-235.

17 Bilici M, Efe H, Koroglu MA, Uydu HA, Bekaroglu M, Deger O: Antioxidative enzyme activities and lipid peroxidation in major depression: alterations by antidepressant treatments. J Affect Disord 2001;64:43-51.

- 18 Herken H, Uz E, Ozyurt H, Sogut S, Virit O, Akyol O: Evidence that the activities of erythrocyte free radical scavenging enzymes and the products of lipid peroxidation are increased in different forms of schizophrenia. Mol Psychiatry 2001;6:66-73.

19 Savas HA, Herken H, Yurekli M, Uz E, Tutkun H, Zoroglu SS: Possible role of nitric oxide and adrenomedullin in bipolar affective disorder. Neuropsychobiology 2002;45:5761.

20 Kim YR, Park Q, Yu BH: Changes in lymphocyte subsets after short-term pharmacotherapy in patients with panic disorder. Psychiatry Res 2004;128:183-190.

-21 Manfro GG, Pollack MH, Otto MW, et al Cell-surface expression of L-selectin (CD62L) by blood lymphocytes: correlates with affective parameters and severity of panic disorder. Depress Anxiety 2000;11:3137.

22 Herken H, Akyol O, Yilmaz HR, Tutkun H, Savas HA, Ozen ME: Nitric oxide, adenosine deaminase, xanthine oxidase and superoxide dismutase in patients with panic disorder: alterations by antidepressant treatment. Hum Psychopharmacol 2006;21:53-59.

23 American Psychiatric Association (APA) Diagnostic and Statistical Manual of Mental Disorders. Washington, American Psychiatric Press, 1994.

24 First MB, Spitzer LR, Gibbon M, et al: Structured Clinical Interview for Axis I Disorders (SCID-I), Clinical Version. Washington, American Psychiatric Press, 1997.

25 Corapcioglu A, Aydemir O, Yildiz M, et al: Structured Clinical Interview for DSM-IV (SCID-I), Türkçe Formu. Ankara, Hekimler Yayın Birliği, 1999.
26 Bandelow B: Assessing the efficacy of treatments for panic disorder and agoraphobia. 2. The panic and agoraphobia scale. Int Clin Psychopharmacol 1995;10:73-81.

27 Hamilton M: A rating scale for depression. J Neurol Neurosurg Psychiatry 1960;23:5662.

28 Akdemir A, Orsel SD, Dag I, et al: Hamilton Depresyon Derecelendirme Ölçeği (HDDÖ) 'nin geçerliği-güvenirliği ve klinikte kullanım. Psikiyatri Psikofarmakoloji Dergisi 1996;4:251-259.

29 Hamilton M: The assessment of anxiety status by rating. Br J Med Psychol 1959;32:5055.

30 Yazıcı MK, Demir B: Hamilton anksiyete değerlendirme ölçeği, değerlendiriciler arası güvenirlik ve geçerlik çalıșması, Türk Psikiyatri Derg 1998;9:114-117.

31 Fidaner H, Tunca Z, Cimilli C, et al: Clinical characteristics of attacks in panic disorder: a study with Q methodology. Türk Psikiyatri Derg 1998;9:277-283.

32 Orsel S, Guruz O, Akdemir A, Türkçapar H: The determination of panic disorder subtypes according to symptoms. Klinik Psikiyatri 2003;6:204-212.

33 Selvi Y, Ozkol H, Tuluce Y, Besiroglu L, Ozdemir PG: Chronotypes and oxidative stress: is there an association? Biol Rhythm Res DOI: $10.1080 / 09291016.2010 .548927$.

34 Giusti G: Adenosine deaminase; in Bergmeyer HU (ed): Methods of Enzymatic Analysis. New York, Academic Press, 1974, vol 2, pp 1092-1099.

35 Lowry OH, Rosebrough NJ, Farr AL: Protein measurement with the folin phenol reagent. J Biol Chem 1951;193:265-275.

36 Felicity N, Berk M, Dean O, Bush AI: Oxidative stress in psychiatric disorders: evidence base and therapeutic implications. J Int Neuropsychopharm 2008;11:851-876.

37 Sternberg EM: Neural regulation of innate immunity: a coordinated nonspecific host response to pathogens. Nat Rev Immunol 2006;6:318-328.

38 Schleifer SJ, Keller SE, Bartlett JA: Panic disorder and immunity: few effects on circulating lymphocytes, mitogen response, and NK cell activity. Brain Behav Immun 2002;16: 698-705.

39 Faravelli C: Life events preceding the onset of panic disorder. J Affect Disord 1985;9: 103-105.

Ozdemir/Selvi/Ozkol/Tuluce/Besiroglu/ Aydin 
40 Savoia MG, Bernik M: Adverse life events and coping skills in panic disorder. Rev Hosp Clin Fac Med Sao Paulo 2004;59:337-340.

41 Yarpuz AY, Yilmaz A, Soykan A, Elgun S, Kumbasar H: Levels of adenosine deaminase and dipeptidyl peptidase IV in patients with panic disorder. Turk Psikiyatri Derg 2008;9: 149-156.

42 Wright RJ, Rodriguez M, Cohen S: Review of psychosocial stress and asthma: an integrated biopsychosocial approach. Thorax 1998; 53:1066-1074.
43 Friedman BH, Thayer JF: Autonomic balance revisited: panic anxiety and heart rate variability. J Psychosom Res 1998;44:133151.

44 Johnston L: Non-Hodgkin's Lymphomas: Making Sense of Diagnosis, Treatment, and Options. Patient-Centered Guides. Sebastopol, O’Reilly Media, 1999.
45 Ersoy MA, Selek S, Celik H, Erel O, Kaya MC, Savas HA, Herken H: Role of oxidative and antioxidative parameters in etiopathogenesis and prognosis of panic disorder. Int J Neurosci 2008;118:1025-1037.

46 Agargun MY, Kara H: Nocturnal panic in patients with panic disorder: the association with major depression. Eur Psychiatry 1997; 12:42-43.

-47 Massana J, Lopez Risueno JA, Massana G: Subtyping of panic disorder patients with bradycardia. Eur Psychiatry 2001;16:109114. 